\title{
A Snapshot Survey of ICT Integration in South African Schools
}

\author{
Keshnee Padayachee \\ University of South Africa, P.O. Box 392, Pretoria, South Africa
}

\begin{abstract}
Information Communication Technology (ICT) integration in the classroom is often viewed as a panacea towards resolving South Africa's education challenges. However, ICT integration in education in South Africa has been severely limited by operational, strategic and pedagogic challenges. In part, addressing the strategic and operational challenges involves understanding the current landscape of ICT integration in schools. There is scant information on the practical enforcement of ICTs in the classroom. The aim of this research is to determine the extent of ICT usage in South African schools in order to obtain an understanding of the practical enforcement of ICTs at the school level. This study combines both qualitative and quantitative data collection methods in order to provide a rich nuanced perspective of ICT integration in South African schools. The study found that the uptake of technology remains low, on average the frequency of usage per tool type was as follows: contextual tools (41\%), sharing information and ideas tools (29\%), experiential tools (26\%) and reflective dialogue tools (18\%). It was found that teachers are uncertain with respect to the enforcement of e-education while being encumbered by poor infrastructure and lack of skills.
\end{abstract}

Keywords: information communication technology, education

Categories: • Applied computing $\sim$ E-learning • Applied computing $\sim$ Education

Email:

Keshnee Padayachee padayk@unisa.ac.za (CORRESPONDING)

Article history:

Received: 26 Feb 2017

Accepted: 30 Aug 2017

Available online: 13 Oct 2017

\section{INTRODUCTION}

In the Department of Basic Education, RSA (2015b) Action Plan to 2019 report, the Department of Basic Education ('Department of Education') has conceded that technology-enhanced learning has not advanced in South Africa (SA) as predicted. Mooketsi and Chigona (2014) found there was a disparity between government expectations and the practices of teachers. Vandeyar (2015, p. 348) maintains that there are a plethora of studies considering the challenges involved in Information Community Technology (ICT) integration in schools, however explorative studies on the practical enforcement of the e-Education policy 'seemed to have escaped the focus of academic researchers'. Hence studies that expose the enforcement issues are highly relevant as they can be used as a means to improve teacher training in ICT integration. The aim of this study was to gain a snapshot view of

Padayachee, K. (2017). A Snapshot Survey of ICT Integration in South African Schools. South African Computer Journal 29(2), 36-65. https://doi.org/10.18489/sacj.v29i2.463

Copyright (C) the author(s); published under a Creative Commons NonCommercial 4.0 License (CC BY-NC 4.0).

SACJ is a publication of the South African Institute of Computer Scientists and Information Technologists. ISSN 1015-7999 (print) ISSN 2313-7835 (online). 
the extent to which educators in SA use ICT strategies to enhance concept acquisition in learners. This is significant as there is a dire need for universities and government to develop the ICT elements of pedagogic practice in order to train teachers effectively. This study is constructed on the rationale that ICT integration should be meaningful and relevant for teachers and learners.

A deeper understanding of ICT integration in the classroom can be used to bridge the gap between theory and practice in developing new teacher training programmes. Leendertz, Blignaut, Ellis, and Nieuwoud (2015) attempted to develop a guideline for mathematics teachers to infuse ICT into their pedagogy. The authors acknowledged that they could not find an appropriate guideline for the professional development of mathematics teachers with respect to the pedagogical use of ICT. du Plessis and Webb (2012, p. 46) assert that current guidelines 'provide very little information on how teachers and schools are expected to practically integrate or make use of ICT within the South African context.' This study attempted to contribute to the current guidelines by providing a view of ICT integration in education within the South African context.

Smith and Hardman indicate that there is a need for more qualitative studies to obtain a 'nuanced picture of computer usage' (Smith \& Hardman, 2014, p. 22). Adukaite, van Zyl, Er, and Cantoni (2017) also claims that there is a paucity of literature in the field of ICT usage for tourism education in South African schools. A comparable study conducted by Ndlovu (2016) considered the pedagogical value of ICT integration of South African secondary school teachers' practices; however, the study was a case-based study limited to seven teachers. An analogous study by Adu (2016) considered the usage of e-learning facilities by Economic and Management Science teachers $(n=200)$ in secondary schools in the Eastern Cape Province. This study found that most digital tools, such as access to the internet, web based learning, email facilities, and multimedia projectors, 'are not available in secondary schools' (Adu, 2016, p. 1747); this study focussed more on the devices rather than the broad range of software tools that are available for teaching and learning.

Clearly, studies that consider the depth and breadth of the actual usage of digital tools are lacking, which is the aim of this exploratory study. This study combines both qualitative and quantitative data collection methods in order to provide a rich nuanced perspective of ICT integration in South African schools.

The following main question guides this study:

To what extent has the use of ICTs (i.e. digital media, e-learning tools, online services and digital devices) been integrated into the pedagogical and content knowledge in South African schools?

In addition to the central research question, three sub-research questions have guided this study:

i What are the most frequent types of ICTs used for teaching and learning?

ii How are educators integrating ICTs into pedagogical and content knowledge?

iii What is the ICT-related vision of educators and how does this transmute into pedagogical and content knowledge? 
The purpose of the study was to obtain snapshot views of both the current usage and the prospective usage of ICTs in teaching and learning within the South African context, toward the development of practical guidelines intended to optimize the use of ICTs in the classroom. The rest of this paper is structured as follows. Section 2 surveys the general e-education landscape of South Africa. Section 3 presents the conceptual framework for the study. Section 4 explicates the research methodology. In Section 5 the results of the data analysis are presented. Section 6 offers a set of recommendations based on the findings of the study which may contribute to greater acceptance of technology-enhanced learning. The article concludes in Section 7 with possible future research opportunities.

\section{BACKGROUND}

The integration of ICTs in education offers several benefits: sharing of resources and learning environments as well as the promotion of collaborative learning and a general move towards greater learner autonomy (Eze, Adu, \& Ruramayi, 2013). However, technology integration is more than supplying computers and an internet connection; it involves the instantiation of learning activities with pedagogically informed use of ICT tools (Mereku \& Mereku, 2015).

Studies show that few educators have effectively integrated ICTs in the classroom (Nkula \& Krauss, 2014; Padayachee, 2016). The following digital tools have been cited with respect to ICT integration in the classroom: word processors, data projectors, Powerpoint spreadsheets, search engines, interactive whiteboards, mobile technologies, smart phones (emails, blogs, videos etc.), tablets, instant messaging, podcasts, CD-ROMs, Wikipedia, simulations, animations and e-books (Mooketsi \& Chigona, 2014; Mereku \& Mereku, 2015; Assan \& Thomas, 2012; Lorenz, Banister, \& Kikkas, 2015; Batchelor \& Olakanmi, 2015; Govender \& Govender, 2014; Molotsi, 2014; Tamim, Borokhovski, Pickup, \& Bernard, 2015). Accordingly, these studies do indicate that ICTs are being used in the classroom, however, more in-depth knowledge is required towards understanding the categories of technologies used and how this facilitates pedagogy and content knowledge.

Previous studies point to a lack of self-efficacy of teachers (Nkula \& Krauss, 2014) and misconceptions as to why teachers are not engaging with ICTs in the classroom. Tamim et al. (2015, p. 2) assert that 'there is a misconception that by simply putting this technology in the hands of students, educational access issues will be resolved and educational transformation will occur'. There are several factors that negate the use of ICTs in the classroom, these include lack of time (Assan \& Thomas, 2012); lack of clarity regarding the e-Education policy (Vandeyar, 2015), lack of support both in terms of infrastructure and policy (Vandeyar, 2015) and the lack of skills (Msila, 2015). However, one of the major challenges, as identified by Tamim et al. (Tamim et al., 2015), is that the focus is more on the technical aspects rather than the pedagogical and theoretical frameworks.

The e-education policy goal (Department of Basic Education, RSA, 2004, p. 17) as articulated in the Department of Education's draft white paper on e-education is:

Every South African manager, teacher and learner in the general and further education and training bands will be ICT capable (that is, use ICTs confidently and creatively to 
help develop the skills and knowledge they need as lifelong learners to achieve personal goals and to be full participants in the global community) by 2013 .

The Department of Basic Education, RSA (2004) white paper on e-education spells out the framework, objectives, funding, resources and implementation strategies for ICT integration in the classroom at a very basic level. The policy indicates that e-Learning may involve the use of the 'Internet, CD-ROM, software, other media and telecommunications' (Department of Basic Education, RSA, 2004, p. 15) while 'online learning refers more specifically to the use of the Internet and associated web-based applications as the delivery medium for the learning experience' (Department of Basic Education, RSA, 2004, p. 15). Evidently, the policy does not directly identify the categories of technologies that would be used in the curriculum. Vandeyar (2015) indicates that practical enforcement of the e-Education policy is clearly lacking. In a study by Ndlovu (2016) which considered the pedagogical integration of ICTs with seven teachers, they found that inconsistencies in the understanding of policies may be a factor in the slow uptake of ICTs in the classroom.

In the Department of Basic Education, RSA (2015b) 'action plan', the Department of Education defined four key strategies in order to improve ICT integration in education. The strategies involve (i) establishing a link between the usage of ICT in the classroom and learning goals; (ii) understanding the various types of technologies available; (iii) establishing collaborations with stakeholders to drive e-education; and (iv) analysing the status quo of e-education initiatives and their envisioned results. It is evident that the Department of Education is calling for more research to be done in order to determine the categories of technologies that are available and whether these categories of technologies have been or could be integrated successfully.

\section{CONCEPTUAL FRAMEWORK}

From Koehler and Mishra (2009)'s perspective, the successful integration of ICT in the classroom must consider three components: content knowledge (i.e. knowledge of subject matter), pedagogical knowledge (i.e. knowledge of teaching and learning praxis) and technological knowledge (i.e. technical skills). The intersection between them is known as Technological Pedagogical Content Knowledge (TPACK). There are very few tools that hit the 'sweet spot' of TPACK (i.e. a perfect confluence of technology, pedagogy, and content) which should always be the goal of e-education. While it has been suggested that it is necessary for teachers to acquire the knowledge bases of TPACK (Nkula \& Krauss, 2014; A. Chigona \& Chigona, 2013), Padayachee and Mbati (2016) suggest that envisioning the model from a pragmatic perspective such as active learning can be more meaningful to show how 'ICT engages the constructive dimension within active learning' (Koh, 2013, p. 889) due to the convoluted nature of the model.

Consequently, the conceptual framework proposed is based on an active-learning perspective for the incorporation of ICT in the classroom. This framework can make it easier to understand the specific categories of knowledge bases required for teachers. The practical steps provided by Fink (2003), who proposed a holistic model of active learning, is used as a guiding framework.

Active learning focuses on the experiential learning and reflective dialogue. However, in order 
to represent a holistic learning experience, Fink (2003) suggests including the concept of 'getting information and ideas' (designated 'sharing information and ideas'), which can be seen as more passive within the ambit of active learning. The various types of technological tools in Table 1 (adapted from Padayachee and Mbati (2016)) are mapped to an activity type based on the conventional usage of the tool.

As an example, a PowerPoint presentation would match the activity type of sharing 'Information and Ideas' as it is a more passive tool. Tools that require interaction would fall under the experiential activity type (which involves the processes of experiencing, reflecting, thinking and acting (Kolb, 2014)). Experiential learning is learner dependent 'and does not necessarily require a teacher' (Itin, 1999, p. 92), whereas tools that involve collaborative reflection or self-reflection would be considered as being reflective dialogue tools.

One additional category which is orthogonal to the activity type is the contextual tools, as some tools are not used for a specific type of activity. This includes aspects such as hardware and the network infrastructure, which forms the context in which the activities are carried out. This guideline for Technologically Enhanced Active Learning will be used as a lens to interpret the results of the study.

\section{RESEARCH DESIGN AND METHODOLOGY}

As there is scant research on the subject matter, an exploratory research design was proposed using a combination of quantitative and qualitative data collection methods. A non-experimental exploratory survey methodology was designed.

\subsection{Sampling}

The researcher generated a purposive sample of teachers across all disciplines from the selected $(n=34)$ secondary schools in Tshwane South. The sample will not naturally permit generalisations outside the group of sample elements which belies the intent of the study. The sampling strategy represented a combination of convenience and purposive sampling.

As a convenience sampling method was followed, the City of Tshwane Metropolitan which is located in the Gauteng Province was selected as a possible target population based on accessibility and proximity. The purposive sampling criteria considered a confluence of relatively high access to the internet and top performing secondary schools as this may generate best case scenarios of ICT integration in education.

WiFi within the Tshwane region has grown in excess of 700 sites (Jack, 2016) and the roll out of free WiFi is considered to be most advanced with respect to installation and uptake (Gilbert, 2015). It can be argued that access to free internet connectivity would encourage a higher uptake of ICTs in the region and this would satisfy the first criterion of the sampling method. 
Table 1: A guideline for Technologically Enhanced Active Learning (adapted from (Padayachee \& Mbati, 2016))

\begin{tabular}{|c|c|c|}
\hline Activity type & Delivery mode & Categories of software tools \\
\hline $\begin{array}{l}\text { Sharing information } \\
\text { and ideas }\end{array}$ & $\begin{array}{l}\text { Primary \& Secondary Sources } \\
\text { Accessing information \& ideas in } \\
\text { class, out of class, online } \\
\text { More passive }\end{array}$ & $\begin{array}{l}\text { Self-created websites (e.g. Google Sites); } \\
\text { Word-processing programs (e.g. MS Word); } \\
\text { Video editing software (e.g. Final Cut, Movie } \\
\text { Maker, iMovie); Video/Record lessons; } \\
\text { Presentation software (e.g. PowerPoint); } \\
\text { Podcasts/Vodcasts (e.g. via iTunes); Online } \\
\text { video sharing sites (e.g. YouTube); Online } \\
\text { library services; File sharing (e.g. Dropbox); } \\
\text { Downloadable eBooks and electronic texts; } \\
\text { Audio software (e.g. Audacity, Garage Band) }\end{array}$ \\
\hline Experiential & $\begin{array}{l}\text { Doing, Observing } \\
\text { Actual, Simulated } \\
\text { Rich Learning Experiences } \\
\text { Independent of the Teacher }\end{array}$ & $\begin{array}{l}\text { Virtual labs (i.e. interactive simulations in } \\
\text { which students perform experiments); } \\
\text { Statistical software (e.g. SPSS/PASW); Spread } \\
\text { sheet software (e.g. Excel); Software } \\
\text { referencing packages (e.g. Endnote, RefWorks); } \\
\text { Software for qualitative text analysis (e.g. } \\
\text { MaxQDA); Search Engines (e.g. Google); } \\
\text { Online examinations/tests; Multimedia-based } \\
\text { learning software; Internet-based learning } \\
\text { platform (e. g. ANGEL, Moodle, Blackboard); } \\
\text { Graphic software (e.g. Photoshop, Flash); Free } \\
\text { multimedia-based learning software from the } \\
\text { internet (e.g. simulations, animations); } \\
\text { E-Portfolios; Educational computer games; } \\
\text { Computer Simulations I }\end{array}$ \\
\hline Reflective Dialogue & $\begin{array}{l}\text { Self-Reflective or Collaborative } \\
\text { Reflection about the Subject and/or } \\
\text { Learning Process }\end{array}$ & $\begin{array}{l}\text { Online internal forums/newsgroups; Mailing } \\
\text { lists Virtual seminars/webinars; Social Media } \\
\text { (e.g. Twitter, Facebook); Online Slide Sharing } \\
\text { Community (e.g. Slideshare); Blogs (e.g. } \\
\text { Wordpress); 3D Virtual Worlds (e.g. Second } \\
\text { Life); Collaborative Project tools (e.g. Wikis, } \\
\text { Google Docs); Mobile learning tools and } \\
\text { applications (SMS, Whatsapp etc.); Class wiki } \\
\text { (a website on which the pages can be edited by } \\
\text { the learners) }\end{array}$ \\
\hline Contextual tools & \multicolumn{2}{|c|}{$\begin{array}{l}\text { Data Projectors, Bring your own device (smartphones, tablets etc.), Remote access } \\
\text { (electronic resources) refers to the use of electronic resources via computer } \\
\text { networks, Direct Access (electronic resources) (e.g. CD-ROMs), Interactive } \\
\text { Whiteboards (e.g. SmartBoard) }\end{array}$} \\
\hline
\end{tabular}


The second criterion involved selecting high achieving schools from Tshwane District based on the 2015 national senior certificate examination (i.e. a standardised test). From the analysis, Tshwane South was selected as the target population for this study as this district contains a preponderance of high achieving schools. Tshwane South contained the largest proportion of schools that performed over the provincial average of 84.2\% (Department of Basic Education, RSA, 2015c).

The sample was consequently further narrowed down to high achieving schools (i.e. schools performing above the provincial achievement rate $(>=84.2 \%)$ ) in the national senior certificate examinations for 2015 (Department of Basic Education, RSA, 2015a).

\subsection{Instrumentation}

The instrument is divided into two sections (see Appendix A). The first section elicits the respondents' biographical details. The second section contains two structured questions (adapted from ZawackiRichter, Müskens, Krause, Alturki, and Aldraiweesh (2015)). The first structured question was based on the scale of digital tools which was established as a sum scale of 40 items regarding the frequency of use of several digital learning formats (virtual seminars, web-based training, e-portfolios etc.). These items were assessed by means of five-point Likert-scales ( $1=$ 'several times daily' $\ldots 5=$ 'never'). The second structured question which also contained 40 items was based on items related to the subjective benefits of various digital tools. These items were also assessed by means of five-point Likert scales ( $1=$ 'very useful'... $5=$ 'not useful at all'). The technical knowledge was supported by open-ended questions adapted from Graham et al. (2009). The open-ended questions allowed the participants to freely voice their concerns and to make suggestions.

\subsection{Validity and reliability}

The tests for validity include face validity and content validity. Content validity 'is the notion that a test should sample the range of the behaviour that is represented by the theoretical concept being measured' McBurney and White (2009, p. 131). Face validity 'is the idea that a test should appear superficially to test what it's supposed to test' (Ibid.). For content validity, the survey items should identify specific ICT technologies that could possibly be used by teachers. To ensure content validity, the resulting survey was reviewed for clarity and correlation to research objectives by a statistician and a subject matter expert. In addition to content validity, the experts reviewed the survey for face validity. However, the survey developed for this research is the combination of two published instruments hence it has been validated by previous researchers. To ensure validity, multiple sources of evidence namely a quantitative Likert scale questionnaire and an open-ended questionnaire were used in order to explore the extent of ICT usage in SA and to triangulate the findings.

\subsection{Data collection}

The data collection was completed within a two-month period. Principles of beneficence and respect for human dignity were observed during data collection. The participant's right to confidentiality was 


\begin{tabular}{|l|c|c|c|c|}
\hline School & $\mathrm{N}$ & $\mathrm{N}$ & Response rate & Grades \\
\hline A & 60 & 31 & $52 \%$ & $8-12$ \\
B & 55 & 13 & $24 \%$ & $8-12$ \\
C & 20 & 7 & $35 \%$ & $8-12$ \\
D* & 75 & 21 & $28 \%$ & $1-12$ \\
E & 96 & 42 & $44 \%$ & $8-12$ \\
\hline Total & 306 & 114 & $37 \%$ & - \\
\hline \multicolumn{4}{|c|}{ * Comprehensive school with special needs learners }
\end{tabular}

Table 2: Response rates achieved

maintained. The study was approved by the University of South Africa's Research Ethics Committee (College of Graduate Studies) and the Gauteng Department of Education.

\subsection{Scope and limitations}

A limitation of the study was that it was restricted to the Tshwane South District.

\section{DATA ANALYSIS}

All questions were individually analyzed, taking into consideration all the available factors and supported with descriptive analysis. The qualitative data were subjected to thematic analysis.

\subsection{Response rate}

The response rate per school is summarised in Table 2. Only seven schools participated and two schools were eliminated in the analysis as the numbers were too low to conduct any meaningful analysis or comparisons.

\subsection{Profile of participants}

The average age of the teachers was 42.5 years. Most of the teachers were involved in languages, while the least number of teachers were involved in the creative arts (see Figure 1).

The majority of the teachers were female (78\%). Note that one participant did not provide any demographic details. A large proportion of teachers had obtained a first degree while a few teachers had obtained a masters degree. The sample was composed as follows: Diploma $(n=24)$, First Degree $(n=57)$, Honours $(n=24)$, Masters $(n=7)$ and none $(n=1)$.

\subsection{Results}

The raw data was organised by activity type: (i) Sharing Information \& Ideas (ii) Experiential; (iii) Reflective Dialogue and (iv) Contextual Tools in order to obtain a deeper understanding of the 


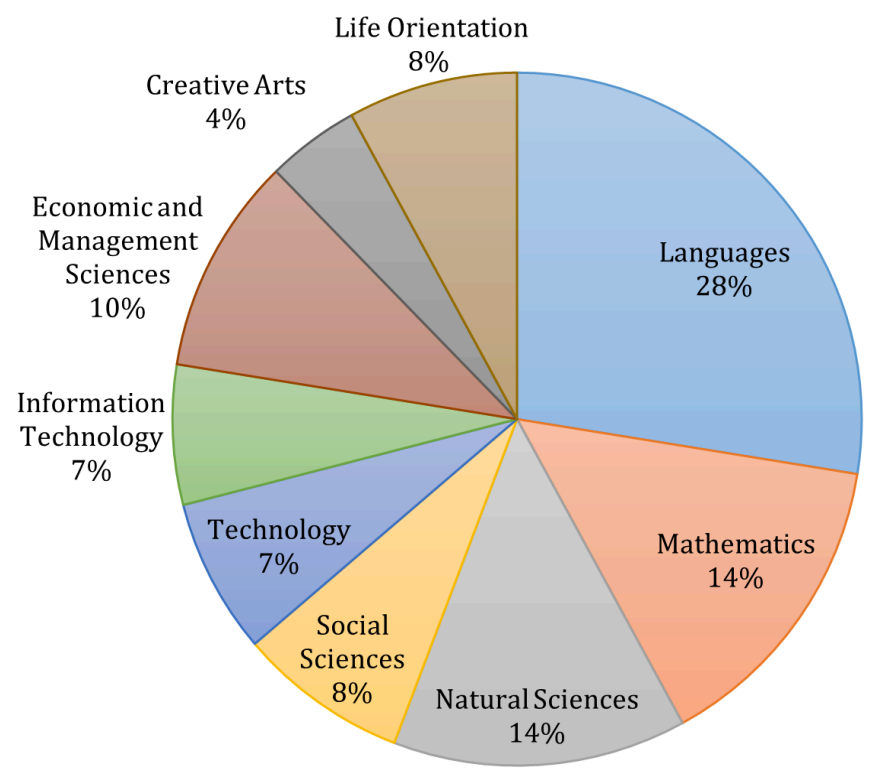

Figure 1: Subject areas of the educators

category of tools used. The raw data was then organised into tables (Tables 3, 4, 5, and 6) where the relative frequency and relative importance of the digital tools, expressed as a percentage, were correlated.

The 'relative frequency' was determined by the percentage of participants that classified the usage of each digital tool with a high-level response. The 'several times a day', 'almost every day' and 'rather irregularly' responses were regarded as high-level responses while the 'rather irregularly' and 'never' responses were regarded as low-level responses.

The 'relative importance' was determined by the percentage of participants that ranked each digital tool as being important (tools ranked 1 and 2). The categories 'very important' and tools ranked of second most importance (i.e. category 2) were grouped to identify those who considered it beneficial to integrate digital tools into their teaching.

\subsubsection{Contextual tools}

The level of awareness of contextual tools is summarised in Table 7. Teachers appear to have the least awareness regarding interactive whiteboards, however teachers appear to have high levels of awareness of BYOD (Bring Your Own Devices) and data projectors. The relative usage frequency and the relative importance of contextual tools are summarised in Table 3. The least frequently used tools are the interactive whiteboards while the most commonly used tools are data projectors and 


\begin{tabular}{|l|c|c|}
\hline Software tools & Relative Frequency & Relative Importance \\
\hline Interactive whiteboards (e.g. SmartBoards) & $10 \%$ & $45 \%$ \\
Direct access electronic resources (e.g. CDROM) & $30 \%$ & $39 \%$ \\
Remote access electronic resources & $33 \%$ & $39 \%$ \\
Bring your own device (smartphones, tablets, etc.) & $62 \%$ & $62 \%$ \\
Data projectors & $69 \%$ & $80 \%$ \\
\hline
\end{tabular}

Table 3: The relative usage frequency and relative importance of context tools

BYODs. Data projectors and BYODs are ranked as relatively important tools while direct access tools and remote access tools appear to be the least important tools.

Additional tools referenced by the participants include $\mathrm{Mimio}^{1}$, eye gazers, mobile recorders, and hover cameras.

\subsubsection{Experiential tools}

On average, teachers have a high level of awareness of spreadsheet software and search engines. Teachers have the least awareness of analysis tools for research such as e-portfolios, software referencing packages, and qualitative text analysis packages. The relative usage frequency and the relative importance of experiential tools are summarised in Table 4. The awareness of experiential tools per school is summarised in Table 8.

The most frequently used tools are search engines while the least frequently used tools are qualitative text analysis tools for research purposes and virtual labs. Spreadsheet software is commonly used as it is a prerequisite. However, the majority of the tools received a low-level response.

The most important tools appear to be search engines while the least important tools appear to be E-Portfolios, software referencing packages and qualitative text analysis packages. The qualitative data collection confirmed that the internet and using Google for searching was used habitually.

The only other tool mentioned that was not on the original list included Computer Aided Design tools (Participant A1). With respect to Computer Simulations, case in points include: using 'Welding simulator(s)' (Participant D9); 'Simulation for science concepts' (Participant E2); 'Scientific simulations to demonstrate difficult concepts' (Participant E6) and 'GIS Simulation (Geographic Information systems)' (Participant B6) were all mentioned.

There appears to be some movement (particularly with respect to School E) towards e-learning platforms. The notion of using Moodle was mentioned by three participants.

\subsection{3 'Sharing information and ideas' tools}

Teachers appear to have the least awareness of Audio software and a high level of awareness of word processing tools, presentation tools, online sharing sites, file sharing sites, downloadable eBooks and

\footnotetext{
${ }^{1}$ Software used with the interactive whiteboards.
} 


\begin{tabular}{|c|c|c|}
\hline Software tools & Relative Frequency & Relative Importance \\
\hline $\begin{array}{l}\text { Software for qualitative text analysis } \\
\text { (e.g. MaxQDA) }\end{array}$ & $4 \%$ & $15 \%$ \\
\hline $\begin{array}{l}\text { Virtual labs (i.e. interactive simulations in which } \\
\text { students perform experiments) }\end{array}$ & $4 \%$ & $28 \%$ \\
\hline $\begin{array}{l}\text { Software referencing packages (e.g. Endnote, } \\
\text { RefWorks) }\end{array}$ & $6 \%$ & $16 \%$ \\
\hline E-Portfolios & $8 \%$ & $18 \%$ \\
\hline Statistical software (e.g. SPSS/PASW) & $9 \%$ & $24 \%$ \\
\hline Computer simulations & $9 \%$ & $32 \%$ \\
\hline Educational computer games & $11 \%$ & $32 \%$ \\
\hline Graphic software (e.g. Photoshop, Flash) & $17 \%$ & $28 \%$ \\
\hline Online examinations/tests & $22 \%$ & $46 \%$ \\
\hline $\begin{array}{l}\text { Internet-based learning platform (e.g. ANGEL, } \\
\text { Moodle, Blackboard) }\end{array}$ & $28 \%$ & $27 \%$ \\
\hline Multimedia-based learning software & $34 \%$ & $39 \%$ \\
\hline $\begin{array}{l}\text { Free multimedia-based learning software from the } \\
\text { internet (e.g. simulations, animations) }\end{array}$ & $37 \%$ & $39 \%$ \\
\hline Spreadsheet software (e.g. Excel) & $83 \%$ & $78 \%$ \\
\hline Search engines (e.g. Google) & $89 \%$ & $84 \%$ \\
\hline
\end{tabular}

Table 4: The relative usage frequency and relative importance of experiential tools 


\begin{tabular}{|c|c|c|}
\hline Software tools & Relative Frequency & Relative Importance \\
\hline Audio software (e.g. Audacity, GarageBand) & $4 \%$ & $21 \%$ \\
\hline Podcasts/Vodcasts (e.g. via iTunes) & $6 \%$ & $11 \%$ \\
\hline $\begin{array}{l}\text { Video editing software (e.g. Final Cut, Movie } \\
\text { Maker, iMovie) }\end{array}$ & $8 \%$ & $23 \%$ \\
\hline Self-created websites (e.g. Google Sites) & $12 \%$ & $20 \%$ \\
\hline Online library services & $18 \%$ & $34 \%$ \\
\hline Video/record lessons & $25 \%$ & $40 \%$ \\
\hline Downloadable eBooks and electronic texts & $25 \%$ & $44 \%$ \\
\hline File sharing (e.g. Dropbox) & $28 \%$ & $44 \%$ \\
\hline Online video sharing sites (e.g. YouTube) & $37 \%$ & $54 \%$ \\
\hline Presentation software (e.g. PowerPoint) & $70 \%$ & $79 \%$ \\
\hline Word-processing programs (e.g. Microsoft Word) & $83 \%$ & $82 \%$ \\
\hline
\end{tabular}

Table 5: The relative usage frequency and relative importance of 'sharing information and ideas' tools

electronic texts.

The relative usage frequency and the relative importance of 'sharing information and ideas' tools are summarised in Table 5. The most frequently used tools are word processing and presentation type software while the least frequently used tools are audio software, podcasts/vodcasts, video editing software and self-created websites. With respect to relative importance; tools such as word processors, presentation software, and online video sharing sites were ranked highly, while the tools such as audio software, self-created websites; video editing software and podcasts/vodcasts were ranked poorly. The awareness of tools used to share information and ideas is summarised per school in Table 9.

The next discussion demonstrates how the participants described the usage of 'sharing information and ideas' tools in the classroom.

With respect to describing the manner in which PowerPoint is used in the classroom, the teachers offered several options:

Participant \#D19: "Visually-Power Point (Poetry/language teaching). Visually \& auditory (social sciences) Videos. Internet-Pictures \& information"

Participant \#A21: "I put all my lessons on a power point presentation where I add relevant pictures and audio to create an interactive classroom environment"

One participant indicated that they 'use Electronic text books' (Participant \#E22) while two participants indicated that they 'use file sharing tools' to share files with learners (Participant \#E8, Participant \#E37). One participant used cloud storage as a backup of their work: "I use Google drive to store my documents/questions/memos" (Participant \#E16). Interestingly one participant (Participant \#E20) indicated, "Drop Box- not available to use at school (not allowed)". 
Online video sharing sites such as YouTube also proved popular. The participants revealed a variety of ways in which they used YouTube and Search Engines to enhance their teaching. For instance:

Participant \#E16: "I would like to search for interesting maths facts/riddles on youtube/google and show them to learners. I would also like to upload my memos on e-studies/google docs"

Participant \#D4: "I use it to create quizzes and games to support and practice new concepts learned. I use videos to support learning and for intervention to support weak learners"

Participant \#D11: "Used projector with videos or pictures to show experiments etc. all day. Also used much information from all digital tegniques[sic] to compile more content for the learners"

Participant \#D13: "Data Projector to view YouTube videos of educational value, laptop to play a variety of educationally enhanced music or sounds"

Participant \#D20: "Download videos to support learning content play music"

Participant \#E34: "YouTube-literature (poetry/novels... ) stimulations [sic]/presentation"

Participant \#D19: "Internet-Pictures and information. Google- analysis \& information \& interesting [sic]"

Participant \#E34: "Google search engine for info/Google images"

\subsubsection{Reflective dialogue tools}

Teachers appear to have a high level of awareness regarding mobile learning tools and applications and social media. However, teachers appear to have the least level of awareness in 3D virtual worlds.

The relative usage frequency and the relative importance of reflective dialogue tools are summarised in Table 6. The most frequently used tools are mobile learning tools, applications and social media, while 3D virtual worlds are the least frequently used tools. The level of awareness of reflective dialogue tools is summarised in Table 10.

The tools ranked most highly (relative importance) include Mobile learning tools and applications while 3D Virtual Worlds and Virtual seminars/webinars are ranked poorly. Evidently, mobile tools are ranked very highly. With respect to using mobile learning tools, a few teachers (Participants \#A12, \#C1, \#E29, \#E39) indicated that they use Whatsapp while two teachers mentioned using Facebook (Participants \#E29, \#E39). With regard to the mobile learning category, teachers consider Whatsapp to be an important tool for dialogue. Interestingly one teacher mentioned using online polls: "I use poll[s] everywhere. Learners use their cellphones to voice their thoughts... appears on 


\begin{tabular}{|l|c|c|}
\hline Software Tools & Relative frequency & Relative importance \\
\hline 3D virtual worlds (e.g. Second Life) & $1 \%$ & $17 \%$ \\
Virtual seminars/webinars & $3 \%$ & $16 \%$ \\
Class wiki (a website on which the pages can be & $4 \%$ & $23 \%$ \\
edited by the learners) & $7 \%$ & $26 \%$ \\
Online slide sharing community (e.g. Slideshare) & $11 \%$ & $22 \%$ \\
Blogs (e.g. WordPress) & $11 \%$ & $18 \%$ \\
Collaborative project tools (e.g. wikis, Google & & $21 \%$ \\
Docs) & $11 \%$ & $34 \%$ \\
Online internal forums/newsgroups & $28 \%$ & $36 \%$ \\
Mailing lists & $42 \%$ & $61 \%$ \\
Social media (e.g. Twitter, Facebook) & $61 \%$ & \\
Mobile learning tools and applications (SMS, & & \\
WhatsApp etc.) & & \\
\hline
\end{tabular}

Table 6: The relative usage frequency and relative importance of reflective dialogue tools

\begin{tabular}{|l|c|c|c|c|c|c|}
\hline Software tools & A (\%) & B (\%) & C (\%) & D (\%) & E (\%) & Weighted (\%) \\
\hline Data projectors & 97 & 100 & 100 & 90 & 93 & 95 \\
Bring your own device & 90 & 100 & 100 & 95 & 95 & 95 \\
Direct access & 81 & 100 & 86 & 90 & 86 & 87 \\
Remote access & 84 & 92 & 86 & 86 & 83 & 85 \\
Interactive whiteboards & 81 & 92 & 86 & 81 & 76 & 81 \\
\hline
\end{tabular}

Table 7: The mean levels of awareness of contextual tools per school

the whiteboard [sic]" (Participant \#E21). One participant indicated how they used social media and mobile learning tools via Whatsapp to enhance their teaching: "Give information and memo's and worksheets via facebook. Help individual learners via WhatsApp". (Participant \#E39).

Tables 7, 8, 9, and 10 are based on the 'do not know them' responses for question 1, part B (see Appendix A). This analysis was used to indicate the general levels of awareness regarding digital tools. Accordingly, these responses were reverse-scored. This information can help to identify research gaps.

\subsubsection{Additional tools}

Participants were asked to list any other digital technologies that they currently use in their teaching process. Teachers listed the following: Computer phone data projector (Participant \#A3); Mimio studio (Participant \#C4); Apps on Smartphones (Participant \#E21); Talking text book (Participant \#D17); Eye gazers. (Participant \#D5) and VS Mobile Recorder for children who cannot read (Participant \#D15) The last three tools appear to be tools for learners with special needs.

Participants were asked to list any other digital technologies that they would like to integrate 


\begin{tabular}{|l|c|c|c|c|c|c|}
\hline Software tools & A (\%) & B (\%) & C (\%) & D (\%) & E (\%) & Weighted (\%) \\
\hline Spreadsheet software & 100 & 100 & 100 & 95 & 93 & 96 \\
Search engines & 97 & 92 & 100 & 100 & 95 & 96 \\
Online examinations/tests & 90 & 92 & 86 & 86 & 93 & 90 \\
Multimedia-based learning & 81 & 77 & 86 & 90 & 90 & 86 \\
software & & & & & & \\
Free multimedia-based learning & 84 & 85 & 71 & 86 & 90 & 86 \\
software from the internet & & & & & & \\
Graphic software & 84 & 85 & 86 & 76 & 86 & 83 \\
Educational computer games & 81 & 92 & 86 & 81 & 83 & 83 \\
Virtual labs & 71 & 77 & 86 & 71 & 81 & 76 \\
Computer Simulations & 68 & 92 & 86 & 67 & 79 & 75 \\
Internet-based learning platform & 65 & 69 & 71 & 67 & 83 & 73 \\
Statistical software & 68 & 69 & 57 & 62 & 76 & 69 \\
E-Portfolios & 61 & 62 & 71 & 67 & 76 & 68 \\
Software referencing packages & 68 & 62 & 57 & 52 & 71 & 65 \\
Software for qualitative text & 65 & 77 & 43 & 52 & 60 & 61 \\
analysis & & & & & & \\
\hline
\end{tabular}

Table 8: The mean levels of awareness of experiential tools per school

\begin{tabular}{|l|c|c|c|c|c|c|}
\hline Software tools & A (\%) & B (\%) & C (\%) & D (\%) & E (\%) & Weighted (\%) \\
\hline Word-processing programs & 100 & 100 & 100 & 95 & 93 & 96 \\
Presentation software & 97 & 100 & 100 & 90 & 95 & 96 \\
Online video sharing sites & 84 & 85 & 100 & 86 & 93 & 89 \\
File sharing & 87 & 92 & 71 & 90 & 90 & 89 \\
Downloadable eBooks and & 94 & 85 & 86 & 86 & 90 & 89 \\
electronic texts & & & & & & \\
Video / Record lessons & 81 & 92 & 100 & 76 & 93 & 87 \\
Your own self-created website & 84 & 85 & 71 & 81 & 81 & 82 \\
Video editing software & 77 & 85 & 86 & 76 & 79 & 79 \\
Podcasts/Vodcasts & 84 & 46 & 86 & 76 & 83 & 78 \\
Online library services & 74 & 85 & 100 & 71 & 79 & 78 \\
Audio software & 74 & 69 & 86 & 67 & 69 & 71 \\
\hline
\end{tabular}

Table 9: The mean levels of awareness of 'sharing of information and ideas' tools per school 


\begin{tabular}{|l|c|c|c|c|c|c|}
\hline Software tools & A (\%) & B (\%) & C (\%) & D (\%) & E (\%) & Weighted (\%) \\
\hline Mobile learning tools and & 94 & 100 & 100 & 95 & 93 & 95 \\
applications & & & & & & \\
Social Media & 94 & 92 & 100 & 90 & 93 & 93 \\
Online internal & 84 & 85 & 86 & 86 & 88 & 86 \\
forums/newsgroups & & & & & & \\
Mailing lists & 81 & 85 & 86 & 71 & 88 & 82 \\
Blogs & 77 & 85 & 71 & 76 & 86 & 81 \\
Collaborative Project tools & 77 & 85 & 86 & 81 & 74 & 78 \\
Virtual seminars/webinars & 74 & 54 & 86 & 76 & 81 & 75 \\
Online Slide Sharing Community & 77 & 69 & 57 & 76 & 79 & 75 \\
Class wiki & 71 & 69 & 86 & 76 & 71 & 73 \\
3D Virtual Worlds & 68 & 69 & 57 & 71 & 71 & 69 \\
\hline
\end{tabular}

Table 10: The mean levels of awareness of 'reflective dialogue' tools per school

into their teaching process in the future. Teachers listed the following tools: 'wi-fi for the classrooms' (Participant \#A20); 'collaborative docs from Google' (Participant \#C1); 'online testing (as a diagnostic assessment tool)' (Participant \#C4); 'software for psychometric testing interpretation' (Participant \#E9); 'Skype' (Participant \#D13); 'touch screen' (Participant \#D17); 'Afrikaans program to read textbooks' (Participant \#D17); 'computer aided tasks, tests, exams' (Participant \#B6) and 'e-box' (Participant \#B8).

\subsubsection{The usage of digital technologies to support teaching and learning}

In response to the question regarding how digital technologies are used to support their teaching process, teachers mentioned how they used technology for their administration and preparation(e.g. MS Word for typing out question papers and Excel for capturing marks). Teachers further indicated that they used technology for research purposes, emailing, filing and sharing files. It also emerged that using technology is considered to be a social responsibility:

Participant \#D22: "I use digital technologies in all subjects, every day, in every possible way that complement my lessons and help learners to improve their knowledge to become better Entrepreneurs one day."

\subsubsection{Barriers to the usage of digital technologies to support teaching and learning}

The principal barriers mentioned were the lack of infrastructure or the inadequacy of the existing infrastructure where the teachers complained that there was no internet access in the classroom or they did not have the necessary tools such as data projectors. The second major issue mentioned was the lack of funding for such projects. Teachers lamented the lack of time, with respect to workload, and interruptions during the school year and the short periods in the year. The next major issue 
was the lack of skills. The next two issues related to power failures and network coverage. With respect to the negative impact of technology on learners, teachers cited discipline, distraction and an overreliance on technology could create complacency in students. Additionally, students may use the technologies to play games. It is interesting to note, that some teachers bear the cost of using technology in the classroom. For example, they use their own data to download material for lessons. Furthermore, they use their own laptops and data projectors. Teachers mentioned that there is often not enough time for them to learn how to use new technologies.

They have also indicated that technology can sometimes fail. The other problem cited is that learners are also not digitally literate and they do not have access to devices such as tablets and smart phones. The principal barriers are represented in Figure 2. Some teachers indicated that technology can be inappropriate for certain subjects such as drama and physical education. Some teachers showed resistance to technology by indicating that they are 'too old to learn new tricks'. Others indicated that there was no support provided and they were concerned about the physical security of the equipment. Other less frequent barriers included: Exponential Rate of Technological Advancement; Information Security Management Cumbersome; Lack of Physical Space (classrooms are shared); Lack of Self-Efficacy; Limited Access to Information on how to use technology; Poor Support for Learners with special needs. and limited resources for indigenous subjects (e.g. Afrikaans).

\subsubsection{Future vision of ICT integration in education}

While most teachers enthusiastically discussed how they could possibly integrate ICTs in the classroom, two teachers admitted their ignorance regarding the subject matter (Participant \#A2 and Participant \#A19). Two other teachers appeared to be uncertain but willing to use technology. The responses ranged from 'I would gladly use everything' (Participant \#A17) to 'Everything will help' (Participant \#D11).

The most coded terms that were extracted from the data included: search engines $(17 \%)$, video (15\%), interactive whiteboards (15\%), e-learning platforms (8\%), data projectors (8\%), PowerPoint $(7 \%)$, BYODs $(6 \%)$ and online assessment $(5 \%)$. It is evident that teachers view search engines, videos and interactive whiteboards as essential tools in the classroom.

There were several mentions of e-learning platforms (8\%). The ideas surrounding Moodle with respect to class collaboration was most often mentioned in relation to this code. Data projectors (8\%) and the use of PowerPoint (7\%) featured relatively often together and could be counted as a single code.

There are several mentions of BYOD devices such as tablets and smartphones (6\%), One participant mentioned (Participant \#C4): "If all my learners had tablets I would share my resources with them on a file sharing platform" while another participant indicated that they would use tablets with structured responses (Participant \#E21): "I would use tablets... Create a virtual classroom... with structured responses". Two participants mentioned that the tablets should be preloaded with 'educational content' and 'educational software'. 


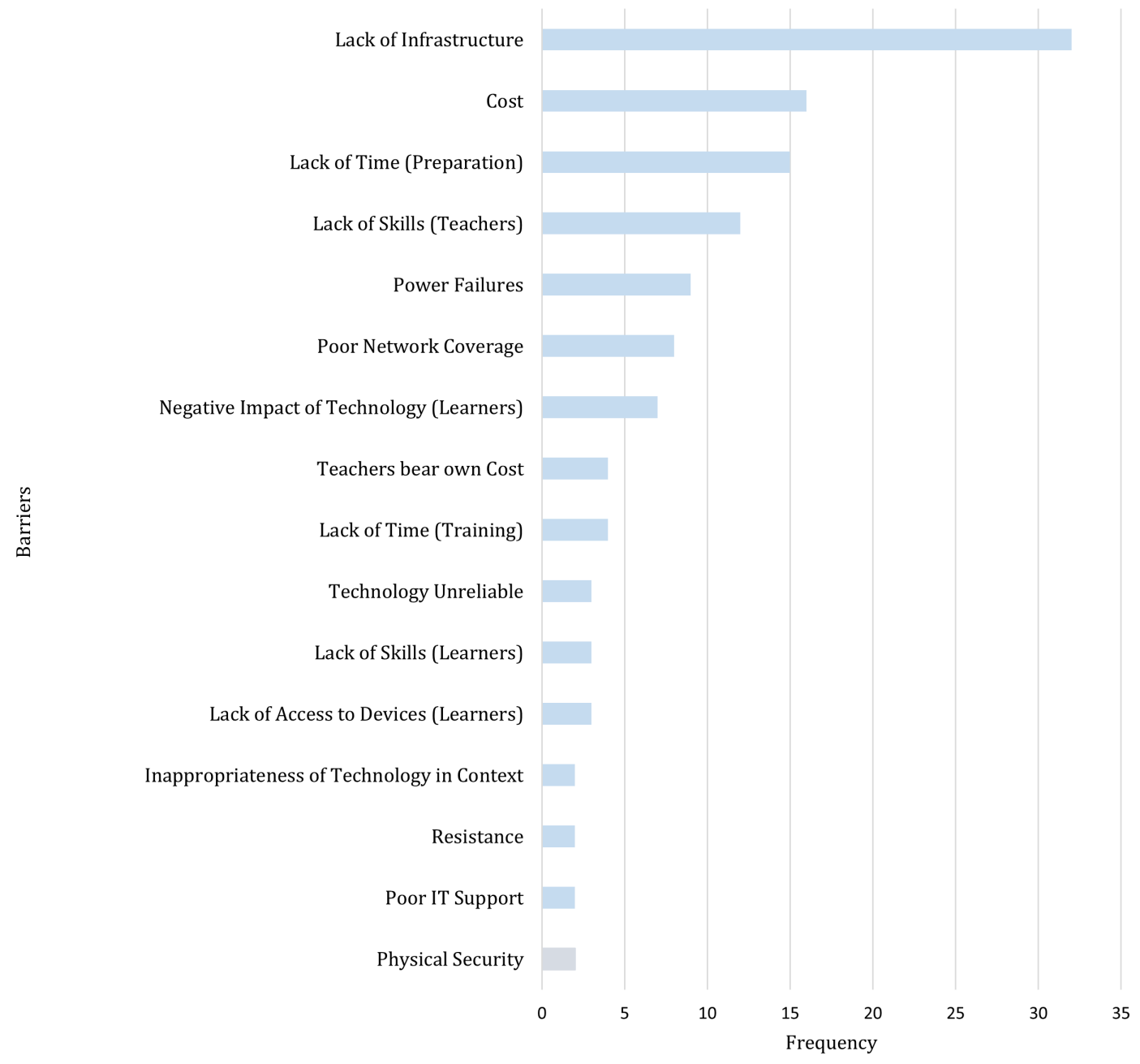

Figure 2: Principal barriers 
There were several mentions of using online assessment (5\%). There were some interesting options listed:

Participant \#B6: "Test concepts with clickers attached to computer. (Fun activity)"

Participant \#E9: "Online psychometric testing, scaring [sic] and interpretation"

The other lesser mentioned codes included: computer games (4\%), computer labs (2\%) mailing lists (1\%), 3D virtual worlds (1\%), e-books (1\%), file sharing (1\%), direct access (1\%), social media (1\%), Google sites (1\%), Google earth (1\%), skype (1\%), graphics software $(1 \%)$, blogs (1\%), touch screen $(1 \%)$, podcast $(1 \%)$ and webinars $(1 \%)$.

Some interesting uses of digital technology were identified from these lesser codes:

Participant \#C1: "I would use Google earth and skype. E.g. teaching poverty - show areas in the world and interview people around the world via Skype, communication with learners to send tests and homework. (Presently done via e-mail). (Google earth + skype)"

There was one interesting altruistic motivation from one participant (note this was not coded as the context of the usage differs from the original intention) where the participant stated that they would like to use 'statistical software to build up a profile of each student to monitor development' (Participant \#E35).

Five participants indicated that they would like to have access to resources and to have support from other teachers (note this was not coded):

Participant \#C2: "Having access to reliable sources may lead to helping with introduction to topic [sic] in Mathematics to show the usefulness of it in real life"

Participant \#C6: "To communicate with universities, Businesses etc. This will assist in project management, data collection, presenting how networks etc. work (mailing lists)"

Participant \#D7: "Connect to other classes and schools worldwide and sharing of good practice"

Participant \#E19: "Like to know about educational computer tools to help with lesson plans e.g. cross word puzzle"

Participant \#E20: “... info sharing between teachers-at the moment available -but not used"

Participant \#E29: "Interactive online support from other teachers. (Online services)"

Participant \#E35: "I would make use of file sharing with fellow teachers and students. (file sharing)"

Clearly teachers are interested in using digital technology in the classroom, however, there may be resistance due to their lack of knowledge. 


\section{RECOMMENDATIONS}

From the issues discovered in Section 5, there are several recommendations towards ensuring the effective implementation of ICT Integration.

\subsection{Upgrade teacher training}

The 'lack of skills' was cited as a reason as to why teachers did not use ICTs in the classroom. ICTs should be integrated into teacher education programs as this will boost confidence and competence of pre-service teachers (A. Chigona \& Chetty, 2012).

\subsection{Access}

Access to technology is an essential requirement towards successful ICT integration in the classroom. Among the individual items, the 'lack of infrastructure' in schools was ranked as the top barrier. It is essential that all learners have equal opportunities for learning with ICTs (Cantrell \& Visser, 2011).

\subsection{Guidelines}

There need to be a set of comprehensive guidelines of how and where ICTs can be effectively deployed (Cantrell \& Visser, 2011). There also needs to be guidelines for students regarding the responsible use of ICTs.

\subsection{Communities of practice and resources}

In order for the national e-Education policy to be practically enforced, teachers should be emboldened to form communities of practice (Vandeyar, 2013). The current study found that teachers are calling for communities of practice to share knowledge and resources. Online resources should be better organised at school level in order to motivate teachers to integrate ICTs into their classrooms (Chikasha, Ntuli, Sundarjee, \& Chikasha, 2014) (e.g. an online resource of ready-made lesson plans (du Plessis \& Webb, 2012)).

\subsection{Incentives}

An incentive scheme to motivate teachers to integrate ICTs in the classroom has been proposed (Chikasha et al., 2014). The current study showed that teachers with social responsibility were motivated towards using ICTs in the classroom. Perhaps teachers could be persuaded to use ICTs by using altruism as an incentive. 


\subsection{Leveraging BYOD devices}

The current study showed that teachers appear to have high levels of knowledge regarding BYOD devices hence this knowledge could be leveraged to encourage the usage of digital technologies in the classroom. It was also suggested that BYOD devices should be preloaded with educational content and software.

\section{DISCUSSION}

With regard to the first research question, we found that the most frequently used contextual type tools included data projectors and BYODs. Only 16\% of teachers have never used a data projector and $20 \%$ have indicated that they have never used BYODs. These tools are considered to be relatively important and teachers have a high level of awareness of these types of tools. In terms of experiential tools: search engines feature as predominant tools. Teachers have a high degree of awareness of search engines and a high level of importance is attached to them. Only $4 \%$ of teachers have never used a search engine. With respect to tools used to share information and ideas, word processors and presentation type tools are used most often. Only $7 \%$ of teachers have never used a word processing package, while only $9 \%$ have never used presentation type software. It appears that online video sharing sites such as YouTube are also popular. With respect to reflective dialogue tools; mobile learning tools and social media tools proved very popular. A minority of teachers (only 20\%) indicated that they never use a mobile learning tool while $35 \%$ indicated that they never use a social media tool. These tools are sufficient to use for technology-enabled active learning in the classroom. Hence it may be a useful investment to capitalize on the teachers' existing knowledge bases rather than to introduce new and unfamiliar technologies.

With regard to the second research question in terms of how educators are integrating ICT in their teaching, it was found that a variety of creative approaches were offered. YouTube can be used for a variety of subjects ranging from mathematics and music to literature. Google is useful for supporting lessons with facts, riddles, audio, and images. BYOD devices can be useful for sharing resources and communication. WhatsApp (a free messaging app) appears to be an important tool for communication while Facebook is purported to be a vital tool for sharing information such as memos and worksheets. Teachers appeared to use ICTs more frequently in their preparation and administration. The possible explanation for this is that teachers have the infrastructure at home for those purposes, but not at school.

With regard to the third question in terms of the ICT-related vision of educators, the most coded terms which were extracted included search engines, video, interactive whiteboards, e-learning platforms, data projectors, PowerPoint, BYODs and online assessments. These tools lean towards using sharing information and ideas and contextual tools which are geared more towards passive learning. While search engines were viewed as an experiential tool for students, teachers viewed them more as a means of obtaining images and data to share with the students, whereas more than half of the tools at the bottom of the list (i.e. least extracted code terms) were either experiential tools or reflective dialogue tools. For instance, computer games, mailing lists, 3D virtual worlds, social 
media, graphics software and blogs had fewer numbers of references. It is clear that teachers need to view technologies as a pedagogical tool and not just a tool to deliver content passively. It is evident that teachers do not have a clear vision with respect to transmuting ICTs into pedagogy. Consequently, there were several references to engaging with communities of practice such as teachers, universities or businesses and including global communities of practice.

On average the frequency of usage per tool type was as follows: contextual tools (41\%), sharing information and ideas tools (29\%), experiential tools (26\%) and reflective dialogue tools (18\%). The relative importance of tool types was as follows: contextual tools (53\%), sharing Information and ideas tools (41\%), experiential tools (36\%) and reflective dialogue tools (27\%). It appears that the usage frequency of the tools and the relative importance attached per tool were correlated. It appears that technological tools that were related to content were preferred over pedagogical tools. It is possible that teachers are more interested in driving the content of the syllabus rather than the experiential and reflective side of teaching.

Extant studies (Nkula \& Krauss, 2014; Msila, 2015) impute the lack of self-efficacy of teachers for the slow progression to ICT integration in the classroom. The current study also highlighted this issue, however, it was minor in comparison to other barriers raised. Analogous to previous studies (Mooketsi \& Chigona, 2014; Mereku \& Mereku, 2015; Assan \& Thomas, 2012) teachers are comfortable with using the internet and word processors to prepare their lessons. Govender and Govender (Govender \& Govender, 2014) found that aspects such as web design, electronic resources and discussion groups, email and electronic references are not widely used, which is consistent with the findings of the current study. Mereku and Mereku (Mereku \& Mereku, 2015) found that educators do not use ICTs to communicate with their students except for those learners who are specifically studying Information Technology as a subject. However, in this study it was found that a large proportion of teachers from various subject areas used mobile learning applications and social media for communication. The ubiquitous nature of mobile phones and social media may be propelling this form of communication amongst teachers across all fields.

While teachers do show enthusiasm, they also show uncertainty regarding how to proceed with ICT integration in the classroom. Hence teachers are calling for knowledge sharing. Similar to previous studies (Adu, 2016), the top issues are the lack of infrastructure and the prohibitive costs. The lack of time together with skill shortages also appear to be tremendous barriers to using ICT in the classroom. The infrastructure issues and the workloads of teachers demand the same level of priority. The other important issue is that students need to be disciplined with respect to using ICTs, as they may become easily distracted by technology. Hence there is a need for guidelines for ICT usage for both teachers and learners.

\section{CONCLUSION}

There appears to be a misconception that merely providing technology can transform education. It is clear that the challenge not only lies with how to use the technology but also with how to integrate digital technologies effectively into the curriculum. The objective of this study was to identify the categories of media, e-learning tools and digital devices already being used that may influence 
further ICT integration by capturing a snapshot of teachers' existing practices. This study drew on the experiential accounts of teachers. The outcomes of the study are likely to be of significance to researchers, teachers and policy makers. Future research will involve deriving a framework of practical guidelines based on technology-based active learning to support educators in achieving effective ICT integration into their teaching practices. The significant purpose of this study is to recommend possible directions involving resources and pedagogical practices that could help educators move closer to embracing technology-enhanced learning.

\section{References}

Adu, E. O. (2016). E-Learning facilities usage assessment by Economic and Management Science (EMS) teachers in Eastern Cape province, South Africa. In EdMedia: World Conference on Educational Media and Technology (pp. 1738-1744). Association for the Advancement of Computing in Education (AACE).

Adukaite, A., van Zyl, I., Er, S., \& Cantoni, L. (2017, August). Teacher perceptions on the use of digital gamified learning in tourism education: The case of South African secondary schools. Computers \& Education, 111, 172-190. https://doi.org/10.1016/j.compedu.2017.04.008

Assan, T. \& Thomas, R. (2012). Information and communication technology integration into teaching and learning: Opportunities and challenges for commerce educators in South Africa. International Journal of Education and Development using Information and Communication Technology, $8(2), 4$.

Batchelor, J. \& Olakanmi, E. E. (2015). Preparing teachers to integrate tablet computers into teaching and learning. In IST-Africa Conference, 2015 (pp. 1-10). IEEE. https://doi.org/10.1109/ ISTAFRICA.2015.7190574

Cantrell, S. \& Visser, L. (2011). Factors influencing the integration of technology to facilitate transfer of learning processes in South African, Western Cape province schools. Quarterly Review of Distance Education, 12(4), 275.

Chigona, A. \& Chetty, R. (2012). Integration of ICTs in teacher education programs in South Africa. In Society for Information Technology \& Teacher Education International Conference (pp. 27482753). Association for the Advancement of Computing in Education (AACE).

Chigona, A. \& Chigona, W. (2013). South African pre-service teachers' under-preparedness to teach with Information Communication Technologies. In e-Learning and e-Technologies in Education (ICEEE), 2013 Second International Conference on (pp. 239-243). IEEE. https://doi.org/10. 1109/ICeLeTE.2013.6644381

Chikasha, S., Ntuli, M., Sundarjee, R., \& Chikasha, J. (2014). ICT integration in teaching: An uncomfortable zone for teachers: A case of schools in Johannesburg. Education as Change, 18(1), 137-150. https://doi.org/10.1080/16823206.2013.847013

Department of Basic Education, RSA. (2004). White paper on e-Education: Transforming learning and teaching through information and communication technologies (ICTs). Last accessed: 9 Aug 2017. Retrieved from http://www.sahistory.org.za/sites/default/files/white\%20\% 5Fpaper\%5Fon\%5Fe-education\%5F2004.pdf 
Department of Basic Education, RSA. (2015a). 2015 National Senior Certificate examination schools performance report. Retrieved from https://www.education.gov.za/Portals/0/Documents/ Reports/2015\%20NSC\%20School\%20Performance\%20Report.pdf?ver=2016-0104-161424-000

Department of Basic Education, RSA. (2015b). Action Plan to 2019: Towards the realisation of Schooling 2030. 26 Sep 2017. Retrieved from https://www.education.gov.za/Portals/0/ Documents/Publications/Action\%20Plan\%202019.pdf?ver =2015-11-11-162424417

Department of Basic Education, RSA. (2015c). National Senior Certificate information booklet. Last accessed: 26 Sep 2016. Retrieved from https://www.education.gov.za/Portals/0/ Documents/Publications/NSC\%20INFORMATION\%20BOOKLET\%202016.pdf?ver= 2017-01-05-110653-900

du Plessis \& Webb, P. (2012, July). Teachers' perceptions about their own and their schools' readiness for computer implementation: A South African case study. Turkish Online Journal of Educational Technology, 11, 312-325.

Eze, R. I., Adu, E. O., \& Ruramayi, T. (2013). The teachers and the use of ICT for professional development in botswana. International Journal of Economy, Management and social Sciences, 2(2), 26-30.

Fink, L. (2003). A self-directed guide to designing courses for significant learning. Last accessed: 9 Aug 2017. Retrieved from http://www.bu.edu/sph/files/2011/06/selfdirected1.pdf

Gilbert, P. (2015). Tshwane leads metros in WiFi access. Last accessed: 26 Sep 2016. Retrieved from http://www.itweb.co.za/index.php?option=com\%5Fcontent\&view=article\&id= 144980

Govender, N. \& Govender, D. (2014, July). Change of science teachers' use of Information and Communication Technology (ICT) media resources and its pedagogical use in science classrooms in a developing country. Journal of Communication, 5, 155-167.

Graham, R., Burgoyne, N., Cantrell, P., Smith, L., St Clair, L., \& Harris, R. (2009). Measuring the TPACK confidence of inservice science teachers. TechTrends, 53(5), 70-79. https://doi.org/10. 1007/s11528-009-0328-0

Itin, C. (1999). Reasserting the philosophy of experiential education as a vehicle for change in the 21st century. Journal of Experiential Education, 22, 91-98. https://doi.org/10.1177/ 105382599902200206

Jack, S. (2016). Tshwane prioritises Internet for development. Last accessed: 23 Jan 2016. Retrieved from http://imnews.co.za/tshwane-prioritises-internet-for-development/

Koehler, M. \& Mishra, P. (2009). What is technological pedagogical content knowledge (TPACK)? Contemporary Issues in Technology and Teacher Education, 9(1), 60-70.

Koh, J. H. L. (2013). A rubric for assessing teachers' lesson activities with respect to TPACK for meaningful learning with ICT. Australasian Journal of Educational Technology, 29(6). https: //doi.org/10.14742/ajet.228

Kolb, D. (2014). Experiential learning: Experience as the source of learning and development. New Jersey: Pearson Education. 
Leendertz, V., Blignaut, A., Ellis, S., \& Nieuwoud, H. (2015, November). The development, validation and standardisation of a questionnaire for ICT professional development of mathematics teachers: Original research. Pythagoras, 36, 1-11. https://doi.org/10.4102/pythagoras. v36i2.297

Lorenz, B., Banister, S. I., \& Kikkas, K. (2015). Impacting the digital divide on a global scale-six case studies from three continents. In International Conference on Learning and Collaboration Technologies (pp. 687-696). Springer. https://doi.org/10.1007/978-3-319-206097\%5F64

McBurney, D. \& White, T. (2009). Research methods. Ohio: Cengage Learning.

Mereku, D. K. \& Mereku, C. W. K. (2015). Congruence between the intended, implemented, and attained ICT curricula in sub-Saharan Africa. Canadian Journal of Science, Mathematics and Technology Education, 15(1), 1-14. https://doi.org/10.1080/14926156.2014.992555

Molotsi, A. (2014). Secondary-school teachers' information communication technology competencies in classroom practices (Doctoral dissertation, Pretoria: University of South Africa).

Mooketsi, B. \& Chigona, W. (2014). Different shades of success: Educator perception of government strategy on e-Education in South Africa. The Electronic Journal of Information Systems in Developing Countries, 64, 1-15.

Msila, V. (2015). Teacher readiness and Information and Communications Technology (ICT) use in classrooms: A South African case study. Creative Education, 6(18), 1973. https://doi.org/10. 4236/ce.2015.618202

Ndlovu, N. (2016). The pedagogical integration of ICTs by seven South African township secondary school teachers (Doctoral dissertation, Johannesburg: University of the Witwatersrand).

Nkula, K. \& Krauss, K. E. (2014). The integration of ICTs in marginalized schools in South Africa: Considerations for understanding the perceptions of in-service teachers and the role of training. In International Development Informatics Association (IDIA) conference (pp. 03-05).

Padayachee, K. (2016). A stepwise framework toward ICT integration in Education: A South African perspective. In 3rd IEEE International Conference on Advances in Computing, Communication and Engineering, Durban, South Africa.

Padayachee, K. \& Mbati, L. (2016). A guiding vision of technology-enabled active learning: A South African perspective. In 2016 Annual Global Online Conference on Information and Computer Technology (GOCICT), Louisville, KY, USA.

Smith, G. \& Hardman, J. (2014, April). The impact of computer and mathematics software usage on performance of school leavers in the Western Cape province of South Africa: A comparative analysis. International Journal of Education and Development using Information and Communication Technology, 10, 22-40.

Tamim, R., Borokhovski, E., Pickup, D., \& Bernard, R. (2015). Large-scale, government-supported educational tablet initiatives. Last accessed: 26 Sep 2017. Retrieved from http://oasis.col. org/handle/11599/809

Vandeyar, T. (2013). Practice as policy in ICT for education: Catalysing communities of practice in education in South Africa. Technology in Society, 35(4), 248-257. https://doi.org/10.1016/j. techsoc.2013.10.002 
Vandeyar, T. (2015, January). Policy intermediaries and the reform of e-Education in South Africa. British Journal of Educational Technology, 46, 344-359. https://doi.org/10.1111/bjet.12130 Zawacki-Richter, O., Müskens, W., Krause, U., Alturki, U., \& Aldraiweesh, A. (2015). Student media usage patterns and non-traditional learning in higher education. The International Review of Research in Open and Distributed Learning, 16(2). https://doi.org/10.19173/irrodl.v16i2. 1979 


\section{A APPENDIX: QUESTIONNAIRE}

\section{Part 1: Biographical and background information}

Please complete the following information:

\begin{tabular}{|l|l|}
\hline Age & \\
\hline Gender & $\square$ Male $\square$ Female \\
\hline What is your highest qualification of education to date? & \\
\hline What subjects and grades do you teach? & \\
\hline
\end{tabular}

\section{Part 2: ICT integration in the classroom}

1. How often do you use the following digital technologies (i.e. digital media, e-learning tools, online services and digital devices) in your teaching process?

\begin{tabular}{|c|c|c|c|c|c|c|}
\hline Digital Technologies & $\begin{array}{l}\text { several } \\
\text { times a } \\
\text { day } \\
1\end{array}$ & $\begin{array}{l}\text { almost } \\
\text { every } \\
\text { day } \\
2\end{array}$ & $\begin{array}{l}\text { regularly } \\
\text { during } \\
\text { the week } \\
3\end{array}$ & $\begin{array}{l}\text { rather } \\
\text { irregu- } \\
\text { larly } \\
4\end{array}$ & $\begin{array}{l}\text { never } \\
5\end{array}$ & $\begin{array}{l}\text { do not } \\
\text { know } \\
\text { them }\end{array}$ \\
\hline $\begin{array}{l}\text { Internet-based learning platform (e.g. } \\
\text { ANGEL, Moodle, Blackboard) }\end{array}$ & & & & & & \\
\hline Online library services & & & & & & \\
\hline File sharing (e.g. Dropbox) & & & & & & \\
\hline E-Portfolios & & & & & & \\
\hline Downloadable eBooks and electronic texts & & & & & & \\
\hline Multimedia-based learning software & & & & & & \\
\hline $\begin{array}{l}\text { Free multimedia-based learning software } \\
\text { from the internet (e.g. simulations, } \\
\text { animations) }\end{array}$ & & & & & & \\
\hline Podcasts/Vodcasts (e.g. via iTunes) & & & & & & \\
\hline Video / Record lessons & & & & & & \\
\hline Online internal forums/newsgroups & & & & & & \\
\hline Mailing lists & & & & & & \\
\hline Virtual seminars/webinars & & & & & & \\
\hline $\begin{array}{l}\text { Software referencing packages } \\
\text { (e.g.Endnote, RefWorks) }\end{array}$ & & & & & & \\
\hline Online examinations/tests & & & & & & \\
\hline $\begin{array}{l}\text { Virtual labs (i.e. interactive simulations in } \\
\text { which students perform experiments) }\end{array}$ & & & & & & \\
\hline Educational computer games & & & & & & \\
\hline Computer Simulations & & & & & & \\
\hline Presentation software (e.g. PowerPoint) & & & & & & \\
\hline $\begin{array}{l}\text { Word-processing programs (e.g. MS } \\
\text { Word) }\end{array}$ & & & & & & \\
\hline
\end{tabular}




\begin{tabular}{|c|c|c|c|c|c|c|}
\hline Digital Technologies & $\begin{array}{l}\text { several } \\
\text { times a } \\
\text { day } \\
1\end{array}$ & $\begin{array}{l}\text { almost } \\
\text { every } \\
\text { day } \\
2\end{array}$ & $\begin{array}{l}\text { regularly } \\
\text { during } \\
\text { the week } \\
3\end{array}$ & $\begin{array}{l}\text { rather } \\
\text { irregu- } \\
\text { larly } \\
4\end{array}$ & $\begin{array}{l}\text { never } \\
5\end{array}$ & $\begin{array}{l}\text { do not } \\
\text { know } \\
\text { them }\end{array}$ \\
\hline Spread sheet software (e.g. Excel) & & & & & & \\
\hline Statistical software (e.g. SPSS/PASW) & & & & & & \\
\hline $\begin{array}{l}\text { Software for qualitative text analysis (e.g. } \\
\text { MaxQDA) }\end{array}$ & & & & & & \\
\hline Graphic software (e.g. Photoshop, Flash) & & & & & & \\
\hline $\begin{array}{l}\text { Audio software (e.g. Audacity, Garage } \\
\text { Band) }\end{array}$ & & & & & & \\
\hline Social Media (e.g. Twitter, Facebook) & & & & & & \\
\hline $\begin{array}{l}\text { Video editing software (e.g. Final Cut, } \\
\text { Movie Maker, iMovie) }\end{array}$ & & & & & & \\
\hline $\begin{array}{l}\text { Online Slide Sharing Community (e.g. } \\
\text { Slideshare) }\end{array}$ & & & & & & \\
\hline Online video sharing sites (e.g. YouTube) & & & & & & \\
\hline Blogs (e.g. Wordpress) & & & & & & \\
\hline Search Engines (e.g. Google) & & & & & & \\
\hline $\begin{array}{l}\text { Your own self-created website (e.g. } \\
\text { Google Sites) }\end{array}$ & & & & & & \\
\hline 3D Virtual Worlds (e.g. Second Life) & & & & & & \\
\hline $\begin{array}{l}\text { Collaborative Project tools (e.g. Wikis, } \\
\text { Google Docs) }\end{array}$ & & & & & & \\
\hline Interactive Whiteboards (SmartBoard) & & & & & & \\
\hline Data Projectors & & & & & & \\
\hline $\begin{array}{l}\text { Bring your own device (smartphones, } \\
\text { tablets etc.) }\end{array}$ & & & & & & \\
\hline $\begin{array}{l}\text { Mobile learning tools and applications } \\
\text { (SMS, Whatsapp etc.) }\end{array}$ & & & & & & \\
\hline $\begin{array}{l}\text { Class wiki (a website on which the pages } \\
\text { can be edited by the learners) }\end{array}$ & & & & & & \\
\hline $\begin{array}{l}\text { Direct Access (electronic resources) (e.g. } \\
\text { CD-ROMs) }\end{array}$ & & & & & & \\
\hline $\begin{array}{l}\text { Remote access (electronic resources) } \\
\text { refers to the use of electronic resources } \\
\text { via computer networks }\end{array}$ & & & & & & \\
\hline
\end{tabular}

2. How useful would you rate the following digital technologies (i.e. digital media, e-learning tools, online services and digital devices) for your teaching process? 


\begin{tabular}{|c|c|c|c|c|c|c|}
\hline Digital Technologies & $\begin{array}{l}\text { very } \\
\text { important } \\
1\end{array}$ & 2 & 3 & 4 & $\begin{array}{l}\text { not } \\
\text { important } \\
\text { at all } \\
5\end{array}$ & $\begin{array}{l}\text { do not } \\
\text { know }\end{array}$ \\
\hline $\begin{array}{l}\text { Internet-based learning platform (e.g. } \\
\text { ANGEL, Moodle, Blackboard) }\end{array}$ & & & & & & \\
\hline Online library services & & & & & & \\
\hline File sharing (e.g. Dropbox) & & & & & & \\
\hline E-Portfolios & & & & & & \\
\hline Downloadable eBooks and electronic texts & & & & & & \\
\hline Multimedia-based learning software & & & & & & \\
\hline $\begin{array}{l}\text { Free multimedia-based learning software } \\
\text { from the internet (e.g. simulations, } \\
\text { animations) }\end{array}$ & & & & & & \\
\hline Podcasts/Vodcasts (e.g. via iTunes) & & & & & & \\
\hline Video / Record lessons & & & & & & \\
\hline Online internal forums/newsgroups & & & & & & \\
\hline Mailing lists & & & & & & \\
\hline Virtual seminars/webinars & & & & & & \\
\hline $\begin{array}{l}\text { Software referencing packages } \\
\text { (e.g.Endnote, RefWorks) }\end{array}$ & & & & & & \\
\hline Online examinations/tests & & & & & & \\
\hline $\begin{array}{l}\text { Virtual labs (i.e. interactive simulations in } \\
\text { which students perform experiments) }\end{array}$ & & & & & & \\
\hline Educational computer games & & & & & & \\
\hline Computer Simulations & & & & & & \\
\hline Presentation software (e.g. PowerPoint) & & & & & & \\
\hline $\begin{array}{l}\text { Word-processing programs (e.g. MS } \\
\text { Word) }\end{array}$ & & & & & & \\
\hline Spread sheet software (e.g. Excel) & & & & & & \\
\hline Statistical software (e.g. SPSS/PASW) & & & & & & \\
\hline $\begin{array}{l}\text { Software for qualitative text analysis (e.g. } \\
\text { MaxQDA) }\end{array}$ & & & & & & \\
\hline Graphic software (e.g. Photoshop, Flash) & & & & & & \\
\hline $\begin{array}{l}\text { Audio software (e.g. Audacity, Garage } \\
\text { Band) }\end{array}$ & & & & & & \\
\hline Social Media (e.g. Twitter, Facebook) & & & & & & \\
\hline $\begin{array}{l}\text { Video editing software (e.g. Final Cut, } \\
\text { Movie Maker, iMovie) }\end{array}$ & & & & & & \\
\hline $\begin{array}{l}\text { Online Slide Sharing Community (e.g. } \\
\text { Slideshare) }\end{array}$ & & & & & & \\
\hline Online video sharing sites (e.g. YouTube) & & & & & & \\
\hline Blogs (e.g. Wordpress) & & & & & & \\
\hline Search Engines (e.g. Google) & & & & & & \\
\hline $\begin{array}{l}\text { Your own self-created website (e.g. } \\
\text { Google Sites) }\end{array}$ & & & & & & \\
\hline 3D Virtual Worlds (e.g. Second Life) & & & & & & \\
\hline
\end{tabular}




\begin{tabular}{|c|c|c|c|c|c|c|}
\hline Digital Technologies & $\begin{array}{l}\text { very } \\
\text { important } \\
1\end{array}$ & 2 & 3 & 4 & $\begin{array}{l}\text { not } \\
\text { important } \\
\text { at all } \\
5\end{array}$ & $\begin{array}{l}\text { do not } \\
\text { know } \\
\text { them }\end{array}$ \\
\hline $\begin{array}{l}\text { Collaborative Project tools (e.g. Wikis, } \\
\text { Google Docs) }\end{array}$ & & & & & & \\
\hline Interactive Whiteboards (SmartBoard) & & & & & & \\
\hline Data Projectors & & & & & & \\
\hline $\begin{array}{l}\text { Bring your own device (smartphones, } \\
\text { tablets etc.) }\end{array}$ & & & & & & \\
\hline $\begin{array}{l}\text { Mobile learning tools and applications } \\
\text { (SMS, Whatsapp etc.) }\end{array}$ & & & & & & \\
\hline $\begin{array}{l}\text { Class wiki (a website on which the pages } \\
\text { can be edited by the learners) }\end{array}$ & & & & & & \\
\hline $\begin{array}{l}\text { Direct Access (electronic resources) (e.g. } \\
\text { CD-ROMs) }\end{array}$ & & & & & & \\
\hline $\begin{array}{l}\text { Remote access (electronic resources) } \\
\text { refers to the use of electronic resources } \\
\text { via computer networks }\end{array}$ & & & & & & \\
\hline
\end{tabular}

\section{Part 3: Contextual information regarding ICT integration}

1. Are there any other digital technologies that you currently use or would like to employ in your teaching process?

2. How do you currently use digital technologies to support your teaching process?

3. What are the barriers to using digital technologies to support your teaching process?

4. Assuming there are no barriers to using digital technologies in your teaching process, if you had access to any digital technologies you wanted to use in teaching a difficult concept in your subject domain, briefly describe what technologies you would use and how you would use them. (NOTE: Digital technologies include digital media, e-learning tools, online services and digital devices.) 